\title{
Aquaculture as Emerging Industry in Sustainable Development in Sundarbans
}

\author{
Anupma kumari * \\ Research scholar Magadh university, Bodh Gaya, India
}

*Corresponding Author: Anupma kumari, Research scholar Magadh university, Bodh Gaya, India

\begin{abstract}
The Sundarban is an UNESCO declared world heritage site, situated at the southern fringes on the West Bengal state of India. Aquaculture plays a vital role in the socio-economic development of the communities living in the Sunderban eco-region. Present study encompasses the prevailing aquaculture practices and socioeconomic profile of the fish farmers of Indian Sundarban based on a multi-layered cross-sectional questionnaire based survey. The majority of fish farmers have medium sized families (60\%) and the aquaculture operations are dominated by male workers (98\%). The fish farmers belonged to low Income group (69\%) and their annual income lies within 785.75 US\$. Majority of the respondent practices traditional type farming (74\%) and polyculture is prevalent. Freshwater aquaculture of Sundarban is dominated by Indian Major Carps (IMCs) in combination with other exotic varieties. Composite fish culture is popular throughout the Sundarban and most preferred stocking combination is carps with tilapia (Oreochromis spp.) followed by IMCs with medium and minor carps. Of Sundarban fish farmers, 19\% do not give any kind of supplementary feed. The survey revealed that the government, educational institutions and NGOs are unsuccessful to develop sustainable aquaculture practice and methods in Sundarban. The state of West Bengal is the second largest fish producer in India (after Andhra Pradesh) and is dominated by production from the South and North 24 Parganas district. Total fish Production of the state was 1.6 million tons in 2000-2001 which was increased to tune up the production of 1.5 million tons in 2013-2014 from an approximately 5.45 lakh ha area. Aquaculture is a rapidly growing food producing sector in the world. Even though capture fishery represented $58 \%$ of total fish production in 2012, it has remained relatively stable throughout the last three decades. The source of significant growth in the global production of fish since the late 1980s has been culture fishery (aquaculture) with an average annual growth rate of $8.8 \% 1$. The production from world food fish aquaculture more than doubled from 32.4 million tons in 2000 to 66.6 million tons in 2012 with an average annual growth rate of 6.2 $\%$ in the period 2000-2012 1. India is the second largest fish producer in the world after China and in 2012 India produced 3.8 million tons farmed food fish from the inland sector 1. In India, national average annual consumption of fish and fish products is $2.85 \mathrm{~kg}$ capita-1 in 2010 which accounts for $2.2 \%$ of total protein consumption

Fishery in Sunderban is the most important and major source of livelihood in the people living there. The forests of Sunderban is located at the situated at the southern fringes on the West Bengal state of India. There are a number of famous tourist spots in the city. Most of the fishermen in the city are from and they use the boats to get their catches from the sea Fishery in sunder ban offers all kinds of fishing activity. There are various types of fishes that are available in the sea. Thus the fishermen have to do some kind of research and study about the fish species so that they can choose the appropriate method of catching them and bring them to the city to sell them to the people. Thus it becomes very important for the people to find out the right way of catching their fishes and get them sold in the market.
\end{abstract}

\section{INTRODUCTION}

Aquaculture is a quickly developing food delivering segment in the world. Despite the fact that catch fishery spoke to $58 \%$ of all out fish creation in 2012, it has remained moderately stable all through the most recent three decades. The wellspring of huge development in the worldwide creation of fish since the late 1980s has been culture fishery (aquaculture) with a normal yearly development pace of $8.8 \% 1$. The creation from world food fish aquaculture dramatically increased from 32.4 million tons in 2000 to 66.6 million tons in 2012 with an normal yearly development pace of $6.2 \%$ in the period 2000-2012 1 . India is the second biggest fish maker on the planet after China also, in 2012 India delivered 3.8 million tons cultivated food fish from the inland part 1 . In India, national normal yearly utilization of fish and fish items is $2.85 \mathrm{~kg}$ capita- 1 out of 2010 which accounts for $2.2 \%$ of all out protein utilization 1 . Consistent declining assets, vitality emergency and significant expense of angling have prompted an 
expanded acknowledgment of aquaculture as a feasible and practical other option to catch fisheries in India 2-4. Inland creation of India has expanded from 5.7 million tons in 2000-2001 to 6.2 million tons in 2013-2014. Out of the all-out inland creation, almost 70\% comes from aquaculture 5. The province of West Bengal is the second biggest fish maker in India (after Andhra Pradesh) and is commanded by creation from the South and North 24 Parganas locale. All out fish creation of the state was 1.6 million tons in 2000-2001 which was expanded to adjust the creation of 1.5 million tons in 2013-2014 from an around 5.45 lakh ha territory 5. In the inland division of India, about 30\% of fish creation originates from the state West Bengal. The inland aquaculture creation of West Bengal expanded from 0.88 million tons in 2000-2001 to 1.39 million tons in 2013-2014 5. The Sundarban Biosphere Reserve (SBR) (organizes lat. $21^{\circ} 402 \mathrm{~N}$ long. $88^{\circ} 032 \mathrm{E}$ to lat. $22^{\circ} 402 \mathrm{~N}$ long. $89^{\circ} 072 \mathrm{E}$ ) is an UNESCO pronounced world legacy site, lies on the southern edges.

In the West Bengal, India, where the Gangetic plain meets the Straight of Bengal. Its 9,630 km2 zone is spread over South 24 Parganas furthermore, southern pieces of the abutting North 24 Parganas, the two southernmost regions of West Bengal. The delta contains 102 low-lying islands, of which 48 islands are involved by human occupying $5,363 \mathrm{~km} 2$ region. Waterway Hoogly, the westernmost estuary of the Sundarban, is the first deltaic branch of stream Ganga. 134 Journal of Food, Agriculture and Environment, Vol.14 (2), April 2016 Stream Raimangal structures the eastern limit of the SBR. The northern restriction of the Sundarban is characterized by the Dampier-Hodges line, a nonexistent line dependent on a review directed during 1829-1832 6. Directly, the settled parts of the SBR are situated in 13 of the 36 squares in South 24 Parganas and on 6 of 22 squares of North 24 Parganas, establishing a sum of 19 squares, alluded as the 'Sundarban squares'. The freshwater streams from the standard streams and the flowing entrance from the ocean bring about a slope of saltiness that shifts both spatially and transiently inside the Biosphere Reserve. When all is said in done, the saltiness is higher closer the coast and the water is almost new on the inland side constraint of the Sundarban where the water is about new 7. The islands of Sundarban are encircled by exceptionally old man-made dikes which make conceivable the presence of freshwater bodies inside the land masses therefore makes farming and freshwater aquaculture reasonable inside this area. Fisheries and aquaculture is a basic part of employment of the occupants of Sundarban and fundamentally adds to the areas' creation. Aside from brackishwater aquaculture, freshwater aquaculture is expanding step by step and making sure about equal economy and employment in Sundarban eco-area. During 2010-2011, South and North 24 Parganas areas created 0.17 and 0.16 million tons' angles, individually, from the inland segment of which about $40 \%$ creation originated from Sundarban squares 8 . Every one of the 19 squares of the Sundarban area have progressively impecunious family units in examination with the comparing midpoints for India and rest of West Bengal, and the level of BPL (Below Poverty Line) a family units' ranges from $31 \%$ to $65 \%$ in these squares 9 . Almost $80 \%$ of the family units procure their living that include wasteful creation techniques in farming, angling, and aquaculture in expansion with numerous stressors 9. Muruganandam et al. 10 referenced that, it is essential to know the functional complexities and least useful information associated with the cultivating to enkindle the reasonable creation of an area. So it is basic to grant legitimate information on the premise of logical advances and accessible chances of fish cultivating to the anglers and fish ranchers to accomplish manageability. Considering the significance and capability of freshwater of Sundarban this correspondence gives data on different experiences on the aquaculture rehearses, creation techniques, obliges alongside financial profile of the fish ranchers of Sundarban.

\section{Materials ANd Methods}

Study territories and test size: The overview was directed in two network improvement squares b of Indian Sundarban to be specific Basanti and Sagar, South 24 Parganas, West Bengal, India (Fig. 1) where aquaculture is prevalently rehearsed. Basanti island (lat. $22^{\circ} 112213 \mathrm{~N}$ and long. $88^{\circ} 402143 \mathrm{E}$ ) is arranged in the eastern part of the Sundarban delta with waterway Bidya on its east, stream Matla on the west, Sandeshkhali-I hinder on its north and Sundarban Tiger Hold in the south. The topographical region of the square is $286.03 \mathrm{~km} 2$. This square comprises of 13 gram panchayats $\mathrm{c}$ and 65 possessed towns. Sagar island (lat. $21^{\circ}$ to $21^{\circ} 53^{\prime} \mathrm{N}$ and long. $88^{\circ} 02^{\prime}$ to $88^{\circ} 15^{\prime} \mathrm{E}$ ) is the biggest deltaic square of Sundarban situated in the outrageous western area of SBR. This island with a region of around $300 \mathrm{~km} 2$ is encircled by two waterways, Hoogly and Muriganga. Both the waterways meet Bay of Bengal on either side of the Sagar island and is completely withdrew from terrain. The square comprises of 9 gram panchayats and 43 towns. The overview secured all out 451 fish cultivating family units disseminated 
more than 20 gram panchayats (244 family units spread across 9 gram panchayats in Sagar square and 207 family units spread across 11 gram panchayats in Basanti square). Advancement of study survey: A cross-sectional multilayered meet based survey was purposively evolved covering all water cultivating attributes for this study. The survey was intended to record data in a norm position with shut inquiries at every possible opportunity and with alteration from different literary works 11-13. Endeavors were made to make the language unambiguous, brief, courteous and non-specialized quite far. Essentially the poll was set up in English and afterward meant Bengali (neighborhood tongue) for successful consequences of the study and for better comprehension of the neighborhood occupants of Sundarban. There was a pre-study meeting when the poll was tried multiple times by meeting objective individuals to distinguish vague and superfluous inquiries as depicted by Khan and Lilley 13. The study poll comprised of four significant classifications, for example (I) financial profile of ranchers, (ii) data on aquaculture, (iii) lake and wellbeing the executives' practices and (iv) issues and need issues. aBelow Poverty Line is a financial benchmark and neediness edge utilized by the legislature of India to demonstrate monetary drawback and to distinguish people and family units needing government help and help. $\mathrm{b}$ The Community advancement square is a provincial zone divided for organization and advancement in India. A people group improvement square covers a few gram panchayats, neighborhood regulatory unit at the town level. gram panchayat is simply the foundation of a neighborhood government association in India of the Panchayati raj framework at the town or humble community level, and has chosen head called Sarpanch or Gram Pradhan.

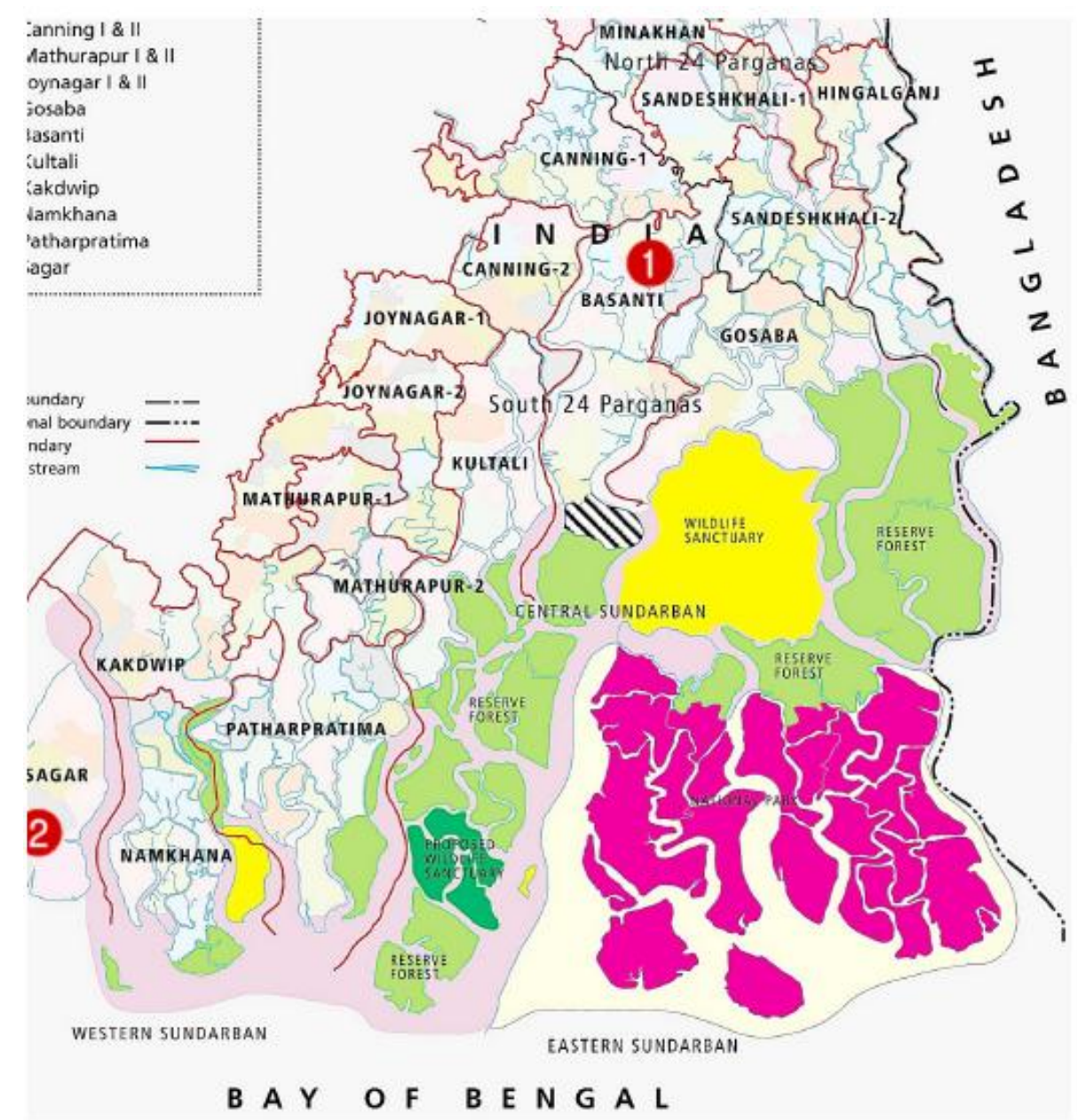

Figure1. Guide of Indian Sundarbans demonstrating study regions. 1 and 2 meant

as Basanti and Sagar square, individually. Diary of Food, Agriculture and Environment, Vol.14 (2), April 2016135 Database readiness and investigation: Data base programming was explicitly created in-house for examination utilizing Microsoft Access TM 2007. The above database programming was utilized for section what's more, stockpiling of studied database. The examinations of whole information were done through Microsoft Excel TM 2007 subsequent to checking the wrong information. Different inductions were attracted relating to pertinent parts of aquaculture rehearses through the assistance of the programming. The examination was led during 2013-2014. 
Table1. Household income of different class

\begin{tabular}{|c|c|c|c|c|c|}
\hline Variable & Description & $\begin{array}{l}\text { Value }(\%) \\
(\mathrm{N}=451)\end{array}$ & Variable & Description & $\begin{array}{l}\text { Value }(\%) \\
(\mathrm{N}=451)\end{array}$ \\
\hline \multirow[t]{5}{*}{ Caste } & General & 40.58 & \multirow{7}{*}{$\begin{array}{l}\text { Educational } \\
\text { qualification }\end{array}$} & Illiterate & 7.76 \\
\hline & SC & 34.59 & & Primary & 12.20 \\
\hline & ST & 3.55 & & $8^{\text {th }}$ standard & 37.69 \\
\hline & $\mathrm{OBC}$ & 7.76 & & $10^{\text {th }}$ standard & 19.96 \\
\hline & Muslim & 13.53 & & $12^{\text {th }}$ standard & 11.31 \\
\hline \multirow[t]{2}{*}{ Gender } & Male & 97.56 & & Graduate & 9.76 \\
\hline & Female & 2.44 & & Post-graduate & 1.33 \\
\hline \multirow{3}{*}{$\begin{array}{l}\text { Household } \\
\text { size }\end{array}$} & $\leq 4$ members & 27.05 & \multirow{5}{*}{$\begin{array}{l}\text { Source of } \\
\text { income }\end{array}$} & Aquaculture with agriculture & 87.58 \\
\hline & $5-8$ members & 60.31 & & Aquaculture with animal husbandry & 25.28 \\
\hline & $>8$ members & 12.64 & & Aquaculture with fishing & 4.21 \\
\hline \multirow{3}{*}{$\begin{array}{l}\text { Annual } \\
\text { income }\end{array}$} & $\leq$ Rs. 50,000 & 68.74 & & Aquaculture with Service & 3.55 \\
\hline & Rs. $50,000-100,000$ & 23.95 & & Aquaculture with business & 17.96 \\
\hline & $>$ Rs. 100000 & 7.32 & \multirow[t]{6}{*}{ Farm size* } & $\leq 0.5$ Bigha & 12.86 \\
\hline Knowledge & Govt. training & 1.77 & & $>0.5$ to 1.0 Bigha & 28.82 \\
\hline \multirow[t]{4}{*}{ source } & NGO training & 2.00 & & $>1.0$ to 3.0 Bigha & 44.79 \\
\hline & From other farmers & 20.40 & & $>3.0$ to 5.0 Bigha & 7.98 \\
\hline & Daily experience & 89.80 & & $>5.0$ Bigha & 5.54 \\
\hline & From mass media & 7.32 & & & \\
\hline
\end{tabular}

\section{RESULTS AND DISCUSSION}

Financial profile, information source and homestead property: In view of rank stratification the neighborhood fish ranchers of Sundarban are characterized in four classes prevalently the general position (41\%) trailed by booked standings (SC) with a portion of $35 \%$ of all out fish ranchers' populace and other two classes viz., other in reverse classes (OBC) and booked clans (ST). Among the respondents, $14 \%$ ranchers have a place with Muslim classification (Table 1). Most of fish ranchers have medium estimated families including of 5-8 relatives (60\%). The aquaculture activities are commanded by male laborers (98\%) in Sundarban and their yearly pay lies between Rs. 50,000 (INR) (785.75 US\$) (69\%). As the fish cultivating is a deep rooted practice in West Bengal, a considerable lot of the ranchers obtained the homesteads from their precursors and the greatest rancher picks up aquaculture information from their day by day cultivating experience (90\%) as opposed to trainings from government and NGOs (2\%). The study results uncovered that the administration, Instructive. . As the fish cultivating is a well-established practice in West Bengal, a significant number of the ranchers gained the homesteads from their predecessors and the greatest rancher picks up aquaculture information from their day by day cultivating experience (90\%) instead of trainings from government and NGOs (2\%). The overview results uncovered that the administration, instructive establishments and NGOs are fruitless to create reasonable aquaculture practice and strategies in Sundarban. The results likewise mirrored the absence of co-appointment and correspondence between government augmentation officials and fish ranchers to execute the logical progressions in aquaculture; and these patterns was notice in India just as in other Asian nations also12, 14. As in Table 1, larger part of ranchers had an instruction up to eighth norm (38\%) and 10\% graduated people were occupied with aquaculture, notwithstanding, contribution of post-graduates were unimportant (2\%). Das et al. 15 saw that instruction and preparing assumed a significant job in reception of improved aquaculture advancements. The outcome uncovered that other than aquaculture, the fish ranchers of the Sundarban squares were likewise included incompletely with agribusiness, creature farming, angling, business, administration and so on as extra wellspring of pay. This pattern is very average in Bangladesh. Of fish ranchers, $88 \%$ practices aquaculture coordinated with agribusiness with a vegetables or manor on the dykes of the lake. Angling is an occasional control of $4 \%$ aquaculture ranchers of Sundarban. Normal farmholdings of lion's share of fish ranchers of Sundarban (45\%) are 0.1-0.4 ha. Just 6\% of ranchers hold all out lake region more than 0.8 ha. As indicated by World Bank 9, despite the fact that about the whole populace of the Indian Sundarban relies upon horticulture, the lion's share of ranches is named "little" and "minimal," with ordinary landholdings of under 1 ha for each family. As per this report, the greater part of all family units of Sundarban had their own property (55.5\%); the holding size was among 0.01 and 0.20 ha. This is fundamentally littler than the normal landholding size of 1.16 ha in India.

\subsection{Cultivating Types, Nursery and Develop Out Tasks}

As appeared in Table 2, about portion of Sundarban ranchers culture both finfish and shellfish (49\%) and $47 \%$ of ranchers only culture finfish. In the squares of Indian Sundarban delta, greater part of 
ranchers rehearses conventional sort cultivating $(74 \%)$ trailed by adjusted broad cultivating practice (23\%). Not many ranchers (3\%) practice semiintensive aquaculture as far as extremely high stocking thickness with outside taking care of. The overview result uncovered that greater part of the aquaculture ranches is lasting sorts (71\%) and are filled through downpour water (69\%). Albeit a small amount of ranchers relies upon ground water alongside downpour water, other than these, ranch lakes get most extreme unscreened and incompletely screened overflow from rural fields commanded by paddy and vegetable yields. As it were 5\% of ranchers do brackishwater culture in the fringe territories yet freshwater aquaculture is transcendent (73\%) inside the islands of Sundarban. As uncovered in Table 2 , scarcely any ranchers are rehearsing The rank framework in India is an arrangement of social definition. Reservation in India is the way toward setting aside a specific level of favorable circumstances for individuals from verifiably in reverse and under-spoke to networks (characterized fundamentally by rank and clan). Reservation is represented by protected laws, legal laws, and nearby guidelines and guidelines. Booked Castes (SC), Scheduled Tribes (ST) and Other In reverse Classes (OBC) are the essential recipients of the booking approaches under the Constitution. monoculture of shrimp in Sundarban squares however fish polyculture is pervasive (87\%) and with an incorporation fundamentally with agriculture and duck raising (8\%). It was seen that greater part of West Bengal ranchers wandered into coordinated cultivating without knowing the genuine advantage 14 . The greater part of the aquaculture ranches of Sundarban are deficient with regards to channel outlet framework. In the Sundarban squares, larger part of the ranchers utilized lake water for numerous reasons like water system, washing and other family unit purposes other than aquaculture (41\%). As the majority of the ranchers working little scope aquaculture, gangs around five develop out lakes and have in any event one major lake (99\%). The after effects of the overview showed that a large portion of the ranchers do not practice nursery raising independently $(86 \%)$ and utilize the growout lakes for developing produce/fry size fish to table size. Nonetheless, $27 \%$ of ranchers have in excess of two nursery lakes which are utilized to stock fish seeds at high densities for raising them to broil and fingerling and moved to develop out lakes. Lake arrangement and seed loading: To guarantee legitimate lake condition and maintainable creation, fish ranchers of Indian Sundarban are rehearsing lake arrangement process by the methods of liming, dewatering, base soil expulsion, de-weeding, annihilation of predators, manuring and so on. As appeared in Table 3, lion's share of fish ranchers works on liming (87\%) trailed by dewatering previously loading (52\%), manuring through cow compost (29\%), de-weeding (18\%) and expulsion of base flotsam and jetsam (21\%). Just 3\% of ranchers do not follow any kind of lake arrangement strategy. It is notable that, appropriate amount of lime is for the most part applied to settle $\mathrm{pH}$ and corrosive base buffering limit, increment accessible phosphorus, quicken decay of natural issue in lake soil; improve lake water quality through at least one compound procedures and control fish parasites or event of sicknesses 17. Deficiency information on significance of essential creation, microscopic fishes, oceanic biological systems and highlights of monetary fish creation, fish ranchers don't have any significant bearing required amount of lime and manures to build lake efficiency and fish creation in the area. Notwithstanding, inordinate utilization of lime, composts and different synthetics may influence water quality, tiny fishes, angles and at last fish creation unfavorably. In West Bengal freshwater aquaculture framework, fish seed showcase furthermore, operators assume an indispensable job in selling the seeds. Countless the ranchers of Sundarban purchased fish seeds from incubation center through the operators. Greatest rancher supplied incubation facility raised seed (87\%) as opposed to loading of normal seeds (2\%). Ranchers of Sundarban are utilized to stock regular (wild) seeds for the most part of Macrobrachium rosenbergii, Penaeus monodon and few brackishwater fish. As it were a not very many part of ranchers stocks both incubation center and wild seeds. Assortment of wild shrimp seed is a consuming issue in the both Indian furthermore, Bangladesh Sundarban as expressed by different specialists already 19-22, what is alluded to as "by-get," the inadvertent disposing of huge quantities of adolescent finfish, shellfish, and other oceanic species. The overexploitation of shrimp fry harshly limits the accessible measure of grown-up shrimp 23 and hampers the common uprightness of riverine biological system. Be that as it may, the present review information mirrors that now daily the mindfulness and discernment of fish ranchers of Sundarban about unfriendly impacts of wild seed assortment have expanded. This is most likely because of mass and aggregate mindfulness approach made by government and NGOs against wild shrimp seed reap. An enormous segment of ranchers of Sundarban squares lean towards continued stocking (70\%) in culture framework. Abraham et al. expressed that the one of a kind trait of West Bengal freshwater fish culture framework is the rehashed loading of fish seeds (81\%) in culture frameworks. Because of the high request of adolescent fish in West Bengal, ranchers gather such size bunches occasionally and renew the gathered stock with 
new fish seeds to keep up the necessary stocking thickness. Single stocking fish seeds is additionally a typical marvel of Sundarban and the current review uncovered that almost 30\% of ranchers like mono stocking which is kept up all through the way of life term. Ranchers of Sundarban for the most part start aquaculture by loading fingerlings (67\%), despite the fact that loading of fry (41\%), hatchlings (6\%) and blended kind of seeds (14\%) are additionally normal. Comparative sort of loading rehearses is additionally seen in Andhra Pradesh14. If there should arise an occurrence of shrimp and prawn, ranchers want to supply of adolescent stages (41\%) rather than post larval stage (PL) (17\%).

Most extreme ranchers like to stock fingerlings up to 3000/bigha (2.25 fish $\mathrm{m}-2$ ) (40\%) where as 32\% ranchers used to stock fingerlings at low stocking thickness, up to 1000/bigha (0.75-1 fish m-2 ). As appeared in Table 3, ranchers of Sundarban typically stock prawn/ shrimp in polyculture framework at low stocking thickness. A perfect fish loading thickness would be $0.5-2.5$ fish $\mathrm{m}-2$ in lakes for carp cultivating, contingent upon size of seedlings 10. The inclination of ranchers for higher stocking thickness is by all accounts an around the world issue and predominant in West Bengal and different conditions of India where aquaculture is in significantly propelled state. Loading in higher thickness would prompt higher mortality, poor development rate, creation of littler table size fishes and at last lower yield also, benefit 10. During the review time frame one basic thing is taken note that a wide range of ranchers in Sundarban don't adjust fish seed before loading just as they don't clean the seed. Loading of seeds without acclimatization were too seen in different conditions of India 10.

Table2. Farming types and grow outs

\begin{tabular}{lll|lll}
\hline Variable & Description & $\begin{array}{l}\text { Value }(\%) \\
(\mathrm{N}=451)\end{array}$ & Variable & Description & $\begin{array}{l}\text { Value (\%) } \\
(\mathrm{N}=451)\end{array}$ \\
\hline Fish type & Finfish & 46.56 & Water type & Freshwater & 72.51 \\
& Shellfish & 6.43 & & Brackishwater & 5.32 \\
& Both & 49.00 & & Both & 22.17 \\
\hline Farming type & Traditional & 73.61 & Cultivation type & Monoculture & 4.88 \\
& Modified Extensive & 23.28 & & Polyculture & 86.92 \\
& Semi-intensive & 3.10 & & Integrated & 8.20 \\
\hline Pond type & Seasonal & 28.82 & Inlet-outlet & Present & 46.12 \\
& Perennial & 70.51 & & Absent & 53.88 \\
\hline Source of & Rain water & 69.40 & Use of pond water & Irrigation only & 6.87 \\
water & Creek & 0.89 & other than & Household and Irrigation & 5.99 \\
& Rain water along with & 23.95 & aquaculture & Household and bathing & 23.50 \\
& ground water & & & & \\
\cline { 1 - 2 } Number of & Nil & 86.03 & & All purpose & 41.46 \\
nursery ponds & $1-3$ & 27.27 & Number of grow- & $\leq 5$ & 98.89 \\
& $>3$ & 1.11 & out ponds & $>5$ & 2.88 \\
\hline
\end{tabular}

Table3. Pond management

\begin{tabular}{|c|c|c|c|c|c|}
\hline Variable & Description & $\begin{array}{l}\text { Value }(\%) \\
(\mathrm{N}=451)\end{array}$ & Variable & Description & $\begin{array}{l}\text { Value }(\%) \\
(\mathrm{N}=451)\end{array}$ \\
\hline \multirow[t]{7}{*}{ Pond preparation } & Dewatering & 51.88 & \multirow[t]{3}{*}{ Source of seeds } & Hatchery & 87.14 \\
\hline & Bottom sediment removal & 21.06 & & Natural & 2.44 \\
\hline & De-weeding & 18.18 & & Both & 10.42 \\
\hline & Eradication & 8.87 & \multirow[t]{2}{*}{ Stocking } & Single & 29.93 \\
\hline & Liming & 87.36 & & Multiple & 70.07 \\
\hline & Manuring & 29.05 & \multirow[t]{4}{*}{ Type of fish seed } & Hatchling & 5.76 \\
\hline & No preparation & 3.55 & & Fry & 40.80 \\
\hline \multirow[t]{2}{*}{ Type of prawn seed } & $\mathrm{PL}$ & 16.85 & & Fingerling & 66.74 \\
\hline & Juvenile & 40.58 & & Mixed & 14.25 \\
\hline Seed acclimatization & No & 83.81 & Seed disinfection & No & 89.58 \\
\hline *Fish seed (pcs) & Hatchling 50,000-100,000 & 2.00 & & Up to 500 & 12.86 \\
\hline \multirow[t]{6}{*}{ stocking rate/Bigha } & $>100,000$ & 1.11 & \multirow{6}{*}{ stocking rate/Bigha } & $501-1000$ & 9.31 \\
\hline & Fry $5,000-10,000$ & 4.43 & & $1001-3000$ & 12.20 \\
\hline & $10,000-50,000$ & 2.00 & & $3001-5000$ & 4.21 \\
\hline & Fingerling up to 1000 & 31.93 & & $5001-10,000$ & 3.77 \\
\hline & $1001-3000$ & 40.35 & & $10,001-30,000$ & 3.99 \\
\hline & $3001-5000$ & 15.30 & & $30,001-40,000$ & 0.67 \\
\hline
\end{tabular}

*1 Bigha $=1333 \mathrm{~m}^{2} ; 10,000 \mathrm{~m}^{2}=1$ hectare (ha) 


\subsection{Refined Species, Loading Mix and Advantageous Taking Care Of}

It is apparent from Table 4 that freshwater aquaculture of Sundarban is ruled by Indian significant carps (IMCs) in blend with other colorful assortments. Labeo rohita, catla what's more, Cirrhinus mrigala are most favored culturable species followed by outlandish carps like Hypophthalmychthys molitrix, Ctenopharyngodon idella, Cyprinus carpio, Barbonymus gonionotus and so forth. Same strategies were polished all over West Bengal, stock Oreochromis mossambicus and O. niloticus because of quicker development rate. Brackishwater species like Lates calcarifer, Chelon parsia, Mugil cephalus, Mystus gulio and Penaeus monodon are additionally supplied in freshwater aquaculture arrangement of Sundarban. Not many fish species like Cyprinus carpio and self-enrolling indigenous fish species like Amblypharyngodon mola, Puntius conchonius, Puntius sophore, Pethia ticto, Clarias batrachus, Heteropneustes fossilis, Channa punctata, Channa striata, Anabas testudineus and so forth were presented normally and breed naturally in culture lakes and renew after collect for not many a long time except if deliberately pulverized. Nonetheless, culture of these angles has not spread broadly in Sundarban however these fishes are bringing significant expense in local markets 25. In Bangladesh part of Sundarban, a few fishes are generally refined and are well perceived for occupation, rustic turn of events and healthful security. Loading blend of aquaculture species is one of the most significant rules for better yield and reflects versatile limit of the ranchers. Albeit composite fish culture is famous all through the Sundarban, most favored stocking blend are carps with tilapia (Oreochromis spp.) trailed by IMCs with medium what's more, minor carps (Table 4). Small portion of ranchers favors carps with M. rosenbergii mix (3\%). Scarcely any ranchers $(6 \%)$ want to stock carp in blend with brackish water species. The creation strategies for freshwater aquaculture in Sundarban can be named as "semi improved, low-input carp polyculture" as seen in other Asian nations 16. As appeared in Table 4, 19\% of fish ranchers of Sundarban don't give any sort of valuable feed. Those ranchers' like to follow the 'legends' for higher stocking thickness of fish seedlings and the conviction is "angles develop themselves" without outside feeds. Among the remainder of respondents, $41 \%$ of ranchers supported rice grain and oil cake as feed stuff and $29 \%$ of ranchers utilize business feed accessible in nearby market for keeping up consistent development of fishes. Albeit common food adds to the nourishment of the refined fish 30, the exogenous flexibly of counterfeit food is fundamental for providing supplements, which might be insufficient in common food. In any case, utilization of counterfeit feed influences water quality more than some other administration factors. Taking care of fish at $2-5 \%$ of the body weight is suggested dependent on common efficiency of fishpond 31. Table 4 portrays that $27 \%$ of ranchers give feed once in seven days though $22 \%$ of ranchers feed their fishes every day. Plate taking care of isn't well known in freshwater conventional aquaculture framework in Sundarban. Larger part of the ranchers $(67 \%)$ embrace broadcasting taking care of strategy though about $6 \%$ of ranchers follow pack taking care of strategy. The sack taking care of procedure is a one of a kind strategy for taking care of carps and likely it has originated from Andhra Pradesh. In this technique, void polythene sacks are for the most part cut to hold almost $15-20 \mathrm{~kg}$ feed. At the lower part of these packs, 2-3 lines of holes are made 32. The feed blends are set into these sacks and suspended from bamboo shafts raised in different areas of the lake. Through this taking care of technique, the ranchers had the option to evade feed wastage just as know the quantum of feed devoured by fish. A significant perception of the review is that a few ranchers of Sundarban utilize business poultry feed for angles. Wellbeing and water quality administration, gathering and separately, are liberated from any sorts of sickness episode. Those ranchers who are confronting ailment issues, the regular finfish ailments are epizootic ulcerative condition (EUS) episode (19\%), blade and tail decay (12\%) and lack of healthy sustenance (10\%). Fish sickness in carp ranches has been accounted for in $31 \%$ of the broad homesteads and $24 \%$ of the semiserious ranches at Bangladesh. The most widely recognized sickness issue in freshwater fish in Bangladesh is EUS as detailed by Mazid and Banu. Yearly misfortunes of US\$ 1.0 million because of malady initiated mortality what's more, disabled development were accounted for in carp culture in Andhra Pradesh, India 35-36. It was accounted for that 73\% of the way of life lakes in West Bengal were sickness influenced; most lakes lost 30-40\% of their stock 35-36. As indicated by the respondents, the significant illnesses of shrimp and prawns are dark injury on shell and tail (17\%), darkening of gill (9\%), parasite outgrowth on shell (7\%) and white spot infection (9\%). In the two cases, ailments happened in different blends. Shrimp illnesses are injurious, since they can cause misfortunes from low (interminable) levels up to intense (100\%) mortalities37. Despite the fact that commonness of WSSV is low in Sundarban, episodes due to WSSV can be forestalled by disposing of potential vectors and 
screening of admission water. The polymerase chain response (PCR) used to screen for contaminated $\mathrm{PL}$ is an approach to diminish the danger of WSSV 38. At the point when the fish ranchers were gotten some information about occasional and developing pattern of illness event, the most extreme reactions of ranchers show that there is no particular example of illness event; be that as it may, the vast majority of the ailments episode happened in winter seasons just as during center of the harvest which is in concurrence with the past examinations.

Table4. Stocked combination of fishes

\begin{tabular}{|c|c|c|c|c|c|}
\hline Variable & Description & $\begin{array}{l}\text { Value (\%) } \\
(\mathrm{N}=451)\end{array}$ & Variable & Description & $\begin{array}{l}\text { Value }(\%) \\
(\mathrm{N}=451)\end{array}$ \\
\hline \multirow{20}{*}{$\begin{array}{l}\text { Species } \\
\text { cultured }\end{array}$} & Catla catla & 87.80 & \multirow[t]{7}{*}{ Stocking combination } & \#IMC + exotic carps & 13.53 \\
\hline & Labeo rohita & 89.58 & & $\# \mathrm{IMC}+$ medium and minor carps & 26.39 \\
\hline & Cirrhinus mrigala & 58.76 & & \#IMC + other exotic varieties & 11.31 \\
\hline & Labeo bata & 33.04 & & \#Carps + Tilapia & 37.47 \\
\hline & Labeo calbasu & 2.88 & & \#Carps + Scampi & 3.10 \\
\hline & Chitala chitala & 1.55 & & \#IMC + brackishwater fishes & 6.43 \\
\hline & *Hypophthalmychthys molitrix & 50.11 & & \#Brackishwater fishes + chitol & 0.44 \\
\hline & *Ctenopharyngodon idella & 27.72 & Supplementary feeding & Not done & 19.29 \\
\hline & *Hypophthalmichthys nobilis & 1.11 & \multirow[t]{3}{*}{ Type of fish feed } & Rice bran and oil cake & 41.02 \\
\hline & *Cyprinus carpio & 16.19 & & Farm made & 9.76 \\
\hline & *Barbonymus gonionotus & 39.02 & & Commercial & 29.49 \\
\hline & *Pangassius spp. & 2.88 & \multirow[t]{5}{*}{ Feeding frequency/week } & Daily & 22.17 \\
\hline & *Pygocentrus nattereri & 16.19 & & Once & 26.61 \\
\hline & *Oreochromis spp. & 15.52 & & Twice & 18.63 \\
\hline & Lates calcarifer & 7.32 & & Thrice & 7.54 \\
\hline & Chelon parsia & 7.10 & & Four times & 5.10 \\
\hline & Mugil cephalus & 1.55 & \multirow[t]{4}{*}{ Nature of feeding } & Broadcasting & 66.74 \\
\hline & Mystus gulio & 1.77 & & Tray feeding & 0.44 \\
\hline & Macrobrachium rosenbergii & 12.64 & & Bag feeding & 5.54 \\
\hline & Penaeus monodon & 4.00 & & & \\
\hline
\end{tabular}

A various number of treatment strategies were accounted for during review, be that as it may, liming (37\%) is the most well-known treatment against malady flare-up followed by water trade (4\%). About $1 \%$ of ranchers use mix of synthetic concoctions and anti-infection agents as indicated by the suggestion of compound providers. Be that as it may, as of late some dynamic ranchers use potassium permanganate, copper sulfate, alum, methylene blue, aqua clean and other business brands, in spite of the fact that there is next to no proof of recuperation from sicknesses after utilization of those synthetic concoctions. Among the prophylactic measures, some of the time liming is the best strategy as announced by certain ranchers. Complete depleting of lake water, lake base drying, expulsion of base mud and liming during lake readiness were found to bring about low malady dangers in some aquaculture cultivates in Bangladesh 13. The illnesses didn't appear to cause calamitous misfortunes, most ranchers of Sundarban revealing that solitary a couple of animal varieties kicked the bucket. From Focus Group Conversation (FGD) it is clear that most of ranchers learned the treatment techniques from different ranchers and nearby synthetic providers. Nonetheless, NGOs and government expansion administrations are less every now and again counseled with respect to ailment conclusion. These marvels in Bangladesh were additionally basic. It is apparent from the study that ranchers are less mindful about estimating water $\mathrm{pH}$ and saltiness during aquaculture activities. About $42 \%$ and $61 \%$ of ranchers don't gauge water $\mathrm{pH}$ and saltiness, separately. Among the checked homesteads, $28 \%$ of ranches had good $\mathrm{pH}$ run (7.5-8.5). In Sundarban, $11 \%$ of aquaculture ranches are acidic in nature $(\mathrm{pH}$ $<7.5$ ). Of the freshwater aquaculture ranches, $30 \%$ arranged inside the islands of Sundarban have marginally saline water having around 5 ppt saltiness.

In Sundarban, the ranchers are liked to reap angles every now and again and more than once on account of the high market interest for the propelled fingerlings and adolescent fish. Around half of ranchers incline toward numerous gathering consistently. Be that as it may, the endurance rates during collecting process lies for the most part in the scope of $<60-80 \%$ most likely because of high stocking thickness and non-appropriation of logical administration rehearses 14 . About $81 \%$ of the Sundarban ranchers sold their aquaculture produce legitimately in open nearby sale advertise; though about $6 \%$ of the 
ranchers exchange the fish from their own ranches. Just $4 \%$ of ranchers sell their reaped fish through neighborhood go-between. In West Bengal, ranchers sell their produce either legitimately to shoppers or vagrant merchants who buy fish from makers and sell in the nearby market to extreme customers. It is obvious that immediate offering to shoppers by makers brings an extra pay of Rs. $2.53 \mathrm{~kg}-1$ of fish 40 .

\subsection{Issues and Imperatives}

There are various issues and challenges in freshwater aquaculture in Sundarban. Among them, saline water immersion through penetrate of lake dykes and overtopping (68\%), illness episodes $(61 \%)$, typhoons and tempest floods because of environmental change (53\%), low quality of fish seeds (52\%), absence of augmentation administrations and specialized information (49\%), social issues like burglary $(46 \%)$ and harming (23\%) and unpredictable natures of precipitation (44\%) are significant issues (Fig. 2). Other than these, ranchers' concernment additionally incorporates ill-advised money related help also, absence of adequate credit offices, poor market cost and quality of feeds and so on which has contradictory effect on the advancement of freshwater aquaculture. Numerous zones of Sundarban delta are powerless against saline water immersion and exposed to natural risk during outrageous climate occasions like tornados what's more, storm floods 41. Earthen dikes enveloping the Sundarban islands keep the brackishwater away from the island also, makes freshwater agribusiness conceivable inside the islands. Saline water immersion because of penetrate of waterway dike, ocean level ascent and resulting disintegration combined with visit outrageous climate occasions which influence freshwater fish culture inside the island of Sundarban which is fundamentally freshwater biological system 42 . Abraham et al. 14 expressed that immersion because of flood is profoundly positioned issue in West Bengal. Because of overwhelming showers during July to September, a huge piece of the West Bengal freshwater fish ranches get immersed, at last loosing dominant part of the stock 14. Dry season because of inconsistent conduct of precipitation is at some point revealed from Sundarban.

Farmers incline toward different collecting consistently. In any case, the endurance rates during collecting process lies generally in the scope of $<60-80 \%$ presumably because of high stocking thickness and non-reception of logical administration rehearses 14 . About $81 \%$ of the Sundarban ranchers sold their aquaculture produce legitimately in open nearby sale advertise; while about $6 \%$ of the ranchers exchange the fish from their own ranches. Just $4 \%$ of ranchers sell their gathered fish through neighborhood middle person. In West Bengal, ranchers sell their produce either legitimately to customers or vagrant brokers who buy fish from makers and sell in the neighborhood market to extreme purchasers. It is apparent that immediate offering to customers by makers brings an extra salary of Rs. $2.53 \mathrm{~kg}-1$ of fish 40 .

Issues and requirements: There are various issues and challenges in freshwater aquaculture in Sundarban. Among them, saline water immersion through break of lake dykes and overtopping (68\%), infection episodes (61\%), twisters and tempest floods because of environmental change (53\%), low quality of fish seeds (52\%), absence of expansion administrations and specialized information (49\%), social issues like robbery (46\%) and harming (23\%) and unpredictable natures of precipitation (44\%) are significant issues (Fig. 2). Other than these, ranchers' concernment additionally incorporates illadvised budgetary help also, absence of adequate credit offices, poor market cost and quality of feeds and so on which has contradictory effect on the advancement of freshwater aquaculture. Numerous territories of Sundarban delta are defenseless against saline water immersion and exposed to ecological risk during extraordinary climate occasions like violent winds what's more, storm floods 41 . Earthen dikes enveloping the Sundarban islands keep the brackishwater away from the island furthermore, makes freshwater horticulture conceivable inside the islands.

Saline water immersion because of break of waterway dike, ocean level ascent and resulting disintegration combined with visit outrageous climate occasions which influence freshwater fish culture inside the island of Sundarban which is essentially freshwater environment 42. Abraham et al. 14 expressed that immersion because of flood is exceptionally positioned issue in West Bengal. Because of substantial showers during July to September, a huge piece of the West Bengal freshwater fish ranches get immersed, at last loosing dominant part of the stock 14. Dry spell because of inconsistent conduct of precipitation is at some point detailed from Sundarban. Ailment episodes are not kidding restricting components to aquaculture creation in West Bengal 35 and other Asian countries12. In the midst of a few possibilities aquaculture area is confronting numerous difficulties like constrained accessibility of sources of info, for example, fish seeds 43 and takes care of 44 in required amount at 
crucial occasions and non-selection of suggested rehearses. Absence of innovative information for logical fish cultivating, absence of institutional help what's more, specialized skill and social issues were accounted for as normal issues in aquaculture part of India.

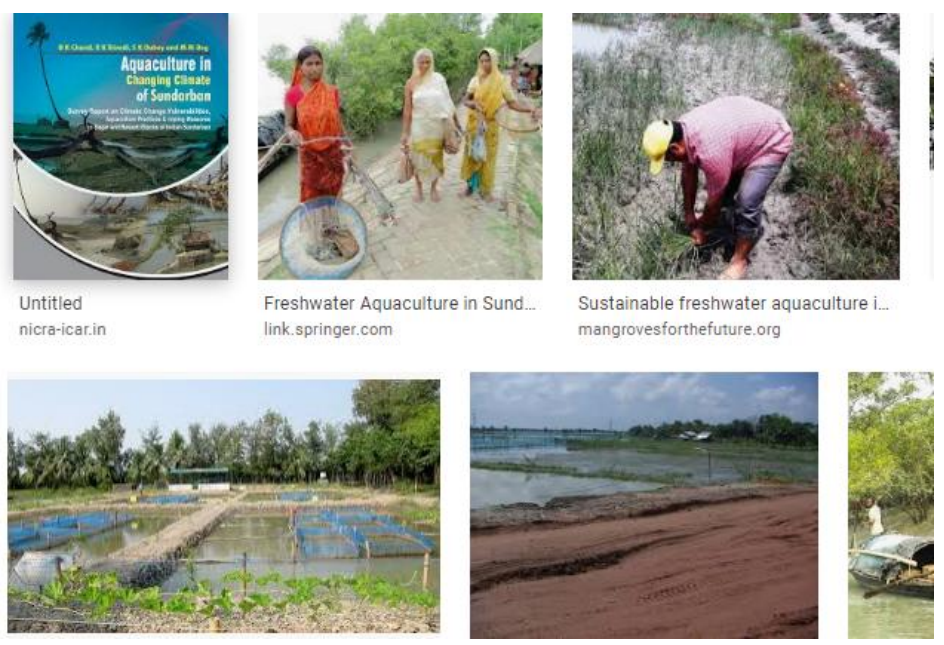

Fig. Sustainable aquaculture: Paddy cum fish culture, Duck cum fish culture

\section{CONCLuSion}

The Indian Sundarban district has a huge potential for freshwater aquaculture improvement in the midst of a few limitations. Improvement of freshwater aquaculture in Sundarban is focused on carp cultivating. It is rehearsed for the most part in terrace lakes. Aquaculture is likewise done in enormous lakes (either possessed by people or scarcely any families), land-forming lakes (for the most part unearthed for horticultural water system reason) and low-lying immersed paddy fields. Reception of present day and logical advances will improve the fish creation and meet the vocation needs of the area. Over reliance of aquaculture on explicit species ought to be kept away from and accentuation ought to be given on species enhancement. Expansion of high worth species ought to likewise be analyzed. Linkage between the fisheries yield and powerful promoting and preparing framework has been powerless in Sundarban area which should be fortified for better come back to the ranchers. Potential moves in flowing examples and saltiness systems will have suggestions for brackishwater aquaculture winning in this locale. To confront these difficulties aquaculture of Sundarban should be bolstered by the proper legitimate and institutional systems just as dynamic collaboration of different partners. A solid specialized, money related and augmentation administrations from government associations what's more, investigate establishments are desperately required for supportable improvement of aquaculture in Sundarban delta.The Indian Sundarban locale has a monstrous potential for freshwater aquaculture advancement in the midst of a few imperatives. Advancement of freshwater aquaculture in Sundarban is focused on carp cultivating. It is drilled generally in lawn lakes. Aquaculture is additionally done in large lakes (either possessed by people or barely any families), land-forming lakes (basically unearthed for farming water system reason) and low-lying immersed paddy fields. Appropriation of present day and logical advancements will improve

\section{REFERENCES}

[1] World Fisheries and Aquaculture: Opportunities and Challenges. Food and Agriculture Organization of the United Nations, Rome, 223 p.

[2] Ayyappan, S. 2000. Technological potential for development of freshwater aquaculture. In Krishnan, M. and Birthal, P.S. (eds). Aquacultural Development of India: Problems and Prospects. National Centre for Agricultural Economics and Policy Research, New Delhi, India, pp. 109-115.

[3] Ayyappan, S. and Jena, J.K. 2001. Sustainable freshwater aquaculture in India. In Pandian, T.J. (eds). Sustainable Indian Fisheries. National Academy of Agricultural Sciences, New Delhi, India, pp. 88-131.

[4] Pillai, N.G.K. and Katiha, P.K. 2004. Evolution of Fisheries and Aquaculture in India. Central Marine Fisheries Research Institute, Kochi, India, 34 p.

[5] Government of India 2014. Handbook on Fisheries Statistics, Ministry of Agriculture, Department of Animal Husbandry, Dairying and Fisheries, Government of India, Krishi Bhavan, New Delhi.

[6] Chatterjee, M., Shankar, D., Sen, G.K., Sanyal, P., Sundar, D., Michael, G.S., Chatterjee, A., Amol, P., Mukherjee, D., Suprit, K., Mukherjee, A., Vijith, V., Chatterjee, S., Basu, A., Das, M., Chakraborti, S., 
Kalla, A., Misra, S.K., Mukhopadhyay, S., Mandal, G. and Sarkar, K. 2013. Tidal variations in the Sundarban estuarine system, India. Journal of Earth System Science 122:899-933.

[7] Gopal, B. and Chauhan, M. 2006. Biodiversity and its conservation in the Sundarban mangrove ecosystem. Aquatic Science 68:338-354.

[8] Government of West Bengal 2010. Annual Report 2010-11. Department of Fisheries, Aquaculture, Aquatic Resources and Fishing Harbours, Government of West Bengal, Salt Lake, Kolkata.

[9] World Bank 2014. Building Resilience for Sustainable Development of the Sundarbans: Through Estuary Management, Poverty Reduction, and Biodiversity Conservation Strategy Report (Report No. 88061 -IN). South Asia region, Sustainable Development Department, Environment and Water Resources Management Unit, The International Bank for Reconstruction and Development, The World Bank, Washington, DC, 290 p.

[10] Muruganandam, M., Pande, R. K., Sharda, V. N., Mishra, P. K. and Raizada, A. 2014. Myths, perceptions and knowledge of farmers on basics of fishes and fish farming in western Himalayas: A review of realities. Indian Journal of Traditional Knowledge 13(1):70-86.

[11] Thrusfield, M. 1995. Veterinary Epidemiology. 2nd edn. Blackwell Science Ltd, London, 496 p.

[12] Arthur, J.R., Phillips, M.J., Subasinghe, R.P., Reantaso, M.B. and Macrae, I.H. (eds). 2002. Primary Aquatic Animal Health Care in Rural, Small-scale, Aquaculture Development. Technical Proceedings of the Asian Regional Scoping Workshop, Dhaka, Bangladesh, 27-30 September, 1999. FAO Fisheries Technical Paper No. 406. FAO, Rome, 382 p.

[13] Khan, M. H. and Lilley, J. H. 2002. Risk factors and socio-economic impacts associated with epizootic ulcerative syndrome (EUS) in Bangladesh. In Arthur, J. R., Phillips, M.J., Subasinghe, R.P., Reantaso, M.B. and Macrae, I.H. (eds). Primary Aquatic Animal Health Care in Rural, Small-scale Aquaculture Development. FAO Fisheries Technical Paper No. 406. FAO, Rome, pp. 27-39.

[14] Abraham, T.J., Sil, S.K. and Vineetha, P. 2010. A comparative study of the aquaculture practices adopted by fish farmers in Andhra Pradesh and West Bengal. Indian Journal of Fisheries 57:41-48.

[15] Das, A., Kumar, N.R., Krishnan, M., Yadav, V.K. and Immanuel, S. 2014. Adoption of improved aquaculture technologies in Tripura, India. Fishery Technology 51:58-63.

[16] Brown, D. and Brooks, A. 2002. A survey of disease impact and awareness in pond aquaculture in Bangladesh, the Fisheries and Training Extension Project-Phase II. In Arthur, J. R., Phillips, M.J., Subasinghe, R.P., Reantaso, M.B. and Macrae, I.H. (eds). Primary Aquatic Animal Health Care in Rural, Small-scale Aquaculture Development. FAO Fisheries Technical Paper No. 406. FAO, Rome, pp. 85-93.

[17] Wilkinson, S. 2002. Aquaculture fundamentals: The use of lime, gypsum, alum and potassium permanganate in water quality management. Aquaculture Asia 7(2):12-14.

[18] Boyd, C.E. and Massaut, L. 1999. Risks associated with the use of chemicals in pond aquaculture. Aquaculture Engineering 20:113-132.

[19] Mitra, A., Mukherjee, A. and Mandal, B. 2006. Notes on the wasted icthyoplankton due to wild harvest of tiger prawn seed from Junput (East Midnapur district), West Bengal. Journal of Environment and Sociobiology 3(2):171-172.

[20] Mukherjee, A. and Mandal, B. 2007. A note on fin fish juveniles wasted during harvest of tiger prawn seed in Chotomollakhali Island, West Bengal. Bionotes 9(4):124.

[21] Hoq, M.E. 2007. An analysis of fisheries exploitation and management practices in Sundarbans mangrove ecosystem, Bangladesh. Ocean and Coastal Management 50:411-427.

[22] Ahmed, N., Occhipinti-Ambrogi, A. and Muir, J.F. 2013. The impact of climate change on prawn postlarvae fishing in coastal Bangladesh: Socioeconomic and ecological perspectives. Marine Policy 39:224- 233.

[23] Knowler, D., Philcox, N., Nathan, S., Delamare, W., Haider, W. and Gupta, K. 2009. Assessing prospects for shrimp culture in the Indian Sundarbans: A combined simulation modelling and choice experiment approach. Marine Policy 33(4):613-623.

[24] MacRae, I. H., Chapman, G., Nabi, S. M. N. and Dhar, G. C. 2002. A survey of health issues in carp/ Macrobrachium culture in rice fields in Bangladesh. In Arthur, J. R., Phillips, M.J., Subasinghe, R.P., Reantaso, M.B. and Macrae, I.H. (eds). Primary Aquatic Animal Health Care in Rural, Small-scale Aquaculture Development. FAO Fisheries Technical Paper No.

Citation: Anupma kumari, “Aquaculture as Emerging Industry in Sustainable Development in Sundarbans", International Journal of Innovative Studies in Aquatic Biology and Fisheries, 6(3), pp. 23-33. DOI: https:// doi.org/10.20431/2454-7670.0603004

Copyright: () 2020 Authors, this is an open-access article distributed under the terms of the Creative Commons Attribution License, which permits unrestricted use, distribution, and reproduction in any medium, provided the original author and source are credited. 